\title{
Recent retreat at a temperate Icelandic glacier in the context of the last $\sim 80$ years of climate change in the North Atlantic region
}

\author{
Benjamin M. P. Chandler ${ }^{1,2}$ - David J. A. Evans ${ }^{1}$ - David H. Roberts ${ }^{1}$
}

Received: 6 June 2016/Accepted: 5 October 2016/Published online: 22 October 2016

(c) The Author(s) 2016. This article is published with open access at Springerlink.com

\begin{abstract}
Over recent decades, glaciers outside of Greenland and Antarctica have displayed accelerating rates of mass loss and ice-frontal retreat, and this has been associated with unequivocal climatic and oceanic warming. Icelandic glaciers are particularly sensitive to climate variations on short-term timescales owing to their maritime setting, and have shown rapid rates of retreat and mass loss during the past decade. This study uses annual moraine spacing as a proxy for ice-frontal retreat to examine variability in glacier retreat at Skálafellsjökull, SE Iceland, over the last $\sim 80$ years. Two pronounced six-year periods (1936-1941 and 1951-1956) of ice-frontal retreat are recognised in the record for comparison with the most recent phase of retreat (2006-2011), and these three retreat phases are shown to be similar in style and magnitude. Analysis of climate data indicates that these periods of glacier retreat are associated with similar summer air temperature values, which is a key control on Icelandic terminus variations. This demonstrates that both the most recent phase of ice-frontal retreat at Skálafellsjökull and the recent warming of summer temperatures are not unusual in the context of the last $\sim 80$ years. These findings demonstrate the importance of placing observations of contemporary glacier change in a broader decadal- to centennial-scale context.
\end{abstract}

Benjamin M. P. Chandler

b.m.p.chandler@qmul.ac.uk

1 Department of Geography, Durham University, South Road, Durham DH1 3LE, UK

2 School of Geography, Queen Mary University of London, Mile End Road, London E1 4NS, UK
Keywords Ice-frontal retreat · Annual moraines · Glacierclimate interactions $\cdot$ Iceland

\section{Introduction}

Glaciers are now losing mass in response to unequivocal atmospheric and oceanic warming, according to the Intergovernmental Panel on Climate Change [31]. This mass loss has contributed to global mean sea-level rise, with mass loss from glaciers and ice-caps accounting for the majority of the recent cryospheric contribution $(\sim 56 \%$ between 1993 and 2010 [31]). Recent studies of glacier mass balance and ice-frontal positions of glaciers outside of Greenland and Antarctica have demonstrated accelerating rates of mass loss and ice-frontal retreat since the 1970s (e.g. [11, 15, 25, 32, 36, 44, 60, 65]). Icelandic glaciers, in particular, are highly sensitive climate indicators owing to their maritime setting, and are particularly sensitive to short-term (annual to decadal-scale) climatic fluctuations $[10,59]$. Over the past decade, studies have demonstrated that Icelandic glaciers have undergone rapid rates of ice-frontal retreat and mass loss (e.g. [7, 10, 29, 46, 59]). Moreover, a recent study at Falljökull [10] has suggested that retreat at this outlet is unprecedented in the context of the last $\sim 80$ years. An assessment of ongoing ice-frontal retreat at other Icelandic outlets is, therefore, of key importance to placing the present period of atmospheric warming and associated glacier retreat in a broader centennial context.

Long, continuous records of ice-front fluctuations form an integral component of monitoring glacier change at regional and global scales, but such detailed records may be absent or incomplete in many localities. Annual moraines, which represent annual ice-frontal variations, offer a 
valuable geomorphological proxy for examining ice-frontal retreat where such records are unavailable (e.g. $[4,9,10,42])$. These features are a characteristic signature of active temperate glaciers in SE Iceland (e.g. $[17,19,20,52])$, and this region is an exemplar for demonstrating the potential of annual moraine records. Previous studies of annual moraines have primarily focused on process-form observations (e.g. [18, 30, 52, 54, 55]), the climatic significance of the moraines (e.g. [4, 9, 10]), or a combination thereof (e.g. [8, 13, 39, 42]). However, there has so far been limited use of annual moraine records to undertake detailed comparisons of variations between phases of ice-frontal retreat within the same record (e.g. [10]), with the emphasis on drivers of the overall pattern.

In this study, we apply annual moraine spacing as a proxy for annual ice-frontal retreat rates of Skálafellsjökull, a major non-surging temperate outlet glacier of the Vatnajökull ice-cap, SE Iceland (Fig. 1), in order to examine variability both within the ice-front record and the associated climate records since the 1930s. Skálafellsjökull has lost $\sim 15 \%$ of its mass since the end of the Little Ice Age [29], but understanding of the behaviour of this glacier is partly limited by a paucity of ice-front measurement data since the 1970s. Annual moraines previously identified on the Skálafellsjökull foreland [13, 19, 55] could, therefore, yield valuable insights into the pattern and rates of recent ice-front retreat at Skálafellsjökull. Our previous contribution on this topic [13] demonstrated that the overall pattern of ice-frontal retreat (moraine spacing) was driven predominantly by variations in summer air temperature. In the present contribution, we take this further by undertaking quantitative analysis to examine differences between the most recent phase of retreat recorded by the annual moraines (2006-2011) and two earlier pronounced phases with an equivalent timespan (1936-1941 and 1951-1956). Moreover, we undertake statistical analyses of climate anomalies associated with these three periods of ice-frontal retreat. The analyses demonstrate that both the most recent phase of icefrontal retreat (2006-2011) and associated climate anomalies are not unusual in the context of the $\sim 80$-year period examined.

\section{Previous research}

\section{Icelandic termini variations}

Regular monitoring of Icelandic glacier termini variations commenced in the 1930s (e.g. [22, 23]), and 41 outlet glaciers, at 55 locations, are currently being actively monitored by Jöklarannsóknafélag Íslands (the Icelandic Glaciological Society: http://spordakost.jorfi.is). This instrumental record reveals that the period 1930-1960 was characterised by rapid retreat of all monitored ice fronts, with retreat occasionally interrupted by surge activity at surge-type glaciers [22, 24, 56, 58, 59]. By 1960, all monitored ice-margins had retreated from their 1930 position, though 10-20\% of glacier termini were advancing in any given year [35, 58, 59]. During the 1940 s and 1960s, the rate of ice-frontal retreat slowed, with many non-surge-type glaciers advancing to varying degrees in the decades following the 1960s (Fig. 2, [58, 59]). During the 1990s, many non-surge-type glaciers recommenced icemarginal retreat, and by 2000 all monitored non-surge-type glaciers were retreating $[57,59]$. Over the past decade, many of the monitored glaciers have shown increasingly rapid rates of ice-marginal retreat (e.g. [10]).

Comparison of non-surge-type glacier termini variations since the 1930s with climate variations shows that ice-front fluctuations are in sympathy with air temperature variations, with warming and cooling trends coinciding with periods of ice-marginal retreat and advance, respectively (Fig. 2, [35, 58, 59]). Relatively high air temperatures during the period 1931-1960, particularly during 1931 and 1940, are associated with a period of rapid ice-front retreat. The reversal of this retreat trend to a period of advance after $\sim 1965$ coincides with a period of climate cooling, and the number of non-surge-type advancing glaciers reached its maximum in the 1975-1990 period following a summer air temperature minimum around 1980 [35, 59]. Icelandic glaciers returned to ice-marginal retreat during the 1990s, particularly after 1995, as temperatures began rising rapidly [57, 59]. Thus, the instrumental record appears to demonstrate that summer air temperature variations exert a dominate control on Icelandic glacier variations [35, 58, 59].

Despite the large body of data on Icelandic glacier termini variations and previous analyses of this (e.g. [59]), as well as a detailed examination of Icelandic climate [28], to date there has been limited quantitative analysis of ice-frontal retreat rates between different periods of retreat and the associated climate variations (e.g. [10]). As such, there are unresolved research issues: (a) Are pronounced periods of Icelandic ice-frontal retreat in the last $\sim 80$ years comparable? (b) Are current rates of icefrontal retreat more rapid than in previous periods in the record? (c) Are prominent periods of ice-frontal retreat, including the present period, associated with comparable climate anomalies? Our contribution explores these issues through inter-comparison and quantitative analysis of icefrontal retreat periods at Skálafellsjökull, with the intention that this will stimulate a detailed assessment of icefrontal retreat rates at a regional scale and highlight the importance of placing ice-frontal retreat in a long-term context. 


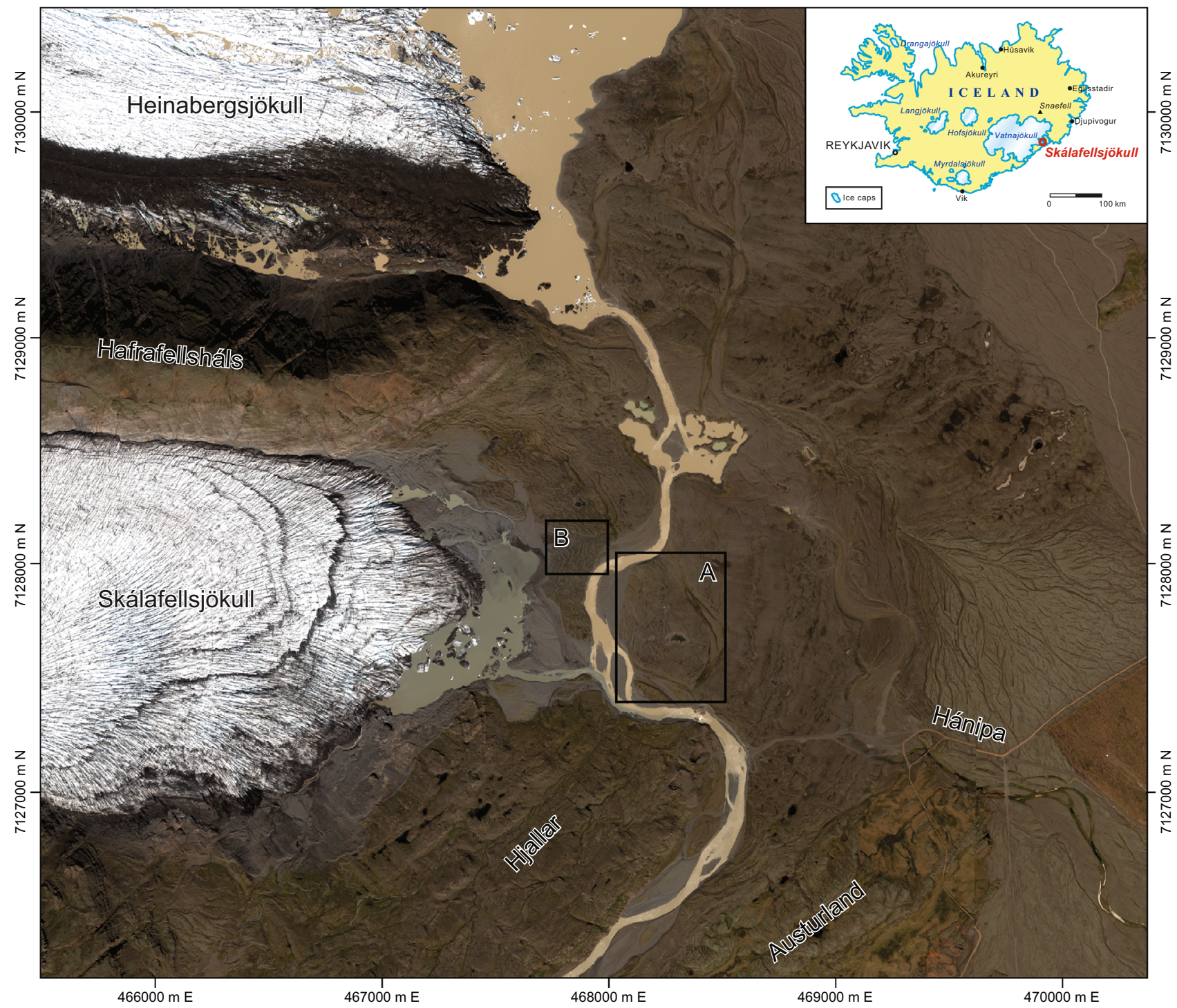

Fig. 1 Multispectral satellite image of the Skálafellsjökull, and neighbouring Heinabergsjökull, foreland. Imagery was captured by the WorldView-2 sensor (June 2012) and supplied by European Space Imaging. The boxes marked $\mathbf{a}$ and $\mathbf{b}$ show the locations of extracts from the geomorphological map of the foreland (Fig. 3a) and

\section{Moraine spacing as a proxy for ice-frontal retreat}

Although a comprehensive database of ice-front measurements exists for Icelandic glaciers, there are extended periods in the records of many outlets where measurements are sporadic/data are incomplete, with Skálafellsjökull being a notable example (see Fig. 2). To circumvent these issues, the spacing between annual moraines can be applied as a geomorphological proxy for ice-frontal retreat rates (e.g. [4, 9, 10, 42]. Small-scale, annual ice-marginal fluctuations manifest in the form of annual moraines in front of many active temperate glaciers in Iceland and elsewhere (e.g. $[8-10,20,30,45,52,54,55,61,63])$. These features form as hillshaded relief models derived from UAV-captured imagery (Fig. 3c), respectively. Scale and orientation are given by the Eastings and Northings. Projection: WGS 1984/UTM Zone $28 \mathrm{~N}$ (ESPG: 32628). Modified from Chandler et al. [14]

a result of short-lived seasonal re-advances during overall retreat (e.g. [1, 8, 39]). Despite an overall net negative mass balance over a number of consecutive years, much-reduced ablation in winter and early spring may result in a temporary switch to seasonally positive mass balance when the glacier snout advances [42]. Provided recession during the ablation season is greater than advance during the accumulation season over consecutive years, a long sequence of inset, consecutively younger annual moraines may be formed $[6,8,42]$. Since the spacing between successive annual moraines equates to the net ice-front recession in a single balance year, annual moraine sequences facilitate the examination of the relationship between annual ice-frontal 


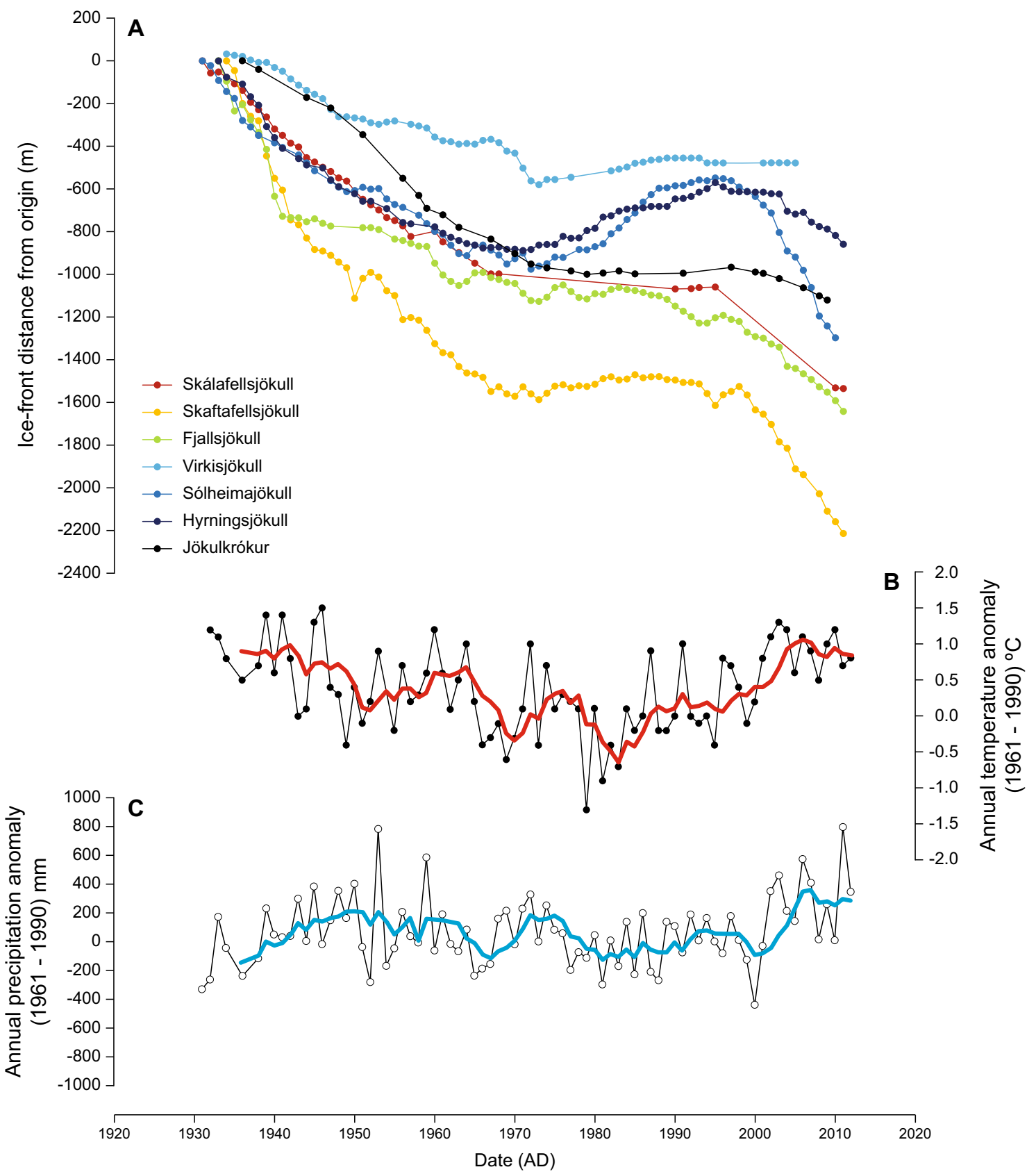

Fig. 2 Ice-front variations at a selection of non-surge-type glaciers from across Iceland (a) and comparison with annual temperature (b) and precipitation (c) variations at Kirkjubæjarklaustur (South Iceland) since 1931. Meteorological data was supplied by Veðurstofa

retreat rates and climate variations (e.g. [4, 9, 10, 42]). Consequently, annual moraines offer the opportunity to link ice-marginal moraines to specific climatic and glaciological conditions, and to increase understanding of glacier dynamics [8, 39, 42, 54]. To date, analyses of the climatological drivers of moraine spacing (ice-frontal retreat) have utilised linear regression and focused on the overall record $[4,9,13,42]$, but there is the opportunity build on this and apply annual moraine records to examine variations between
Íslands (the Icelandic Meteorological Office), whilst glacier termini variations were taken from the Icelandic Glaciological Society database (http://spordakost.jorfi.is)

different periods of retreat within the same record, along with concurrent variations in climate.

In our previous contribution on this topic, we have demonstrated that small-scale recessional (annual) moraines previously identified on the Skálafellsjökull foreland (Fig. 3; $[14,19,55])$ are constructed by a range of genetic processes associated with minor, annual ice-margin re-advance [13]. We subsequently utilised the spacing between these moraines to examine the overall pattern of glacier retreat from the 1930s to 

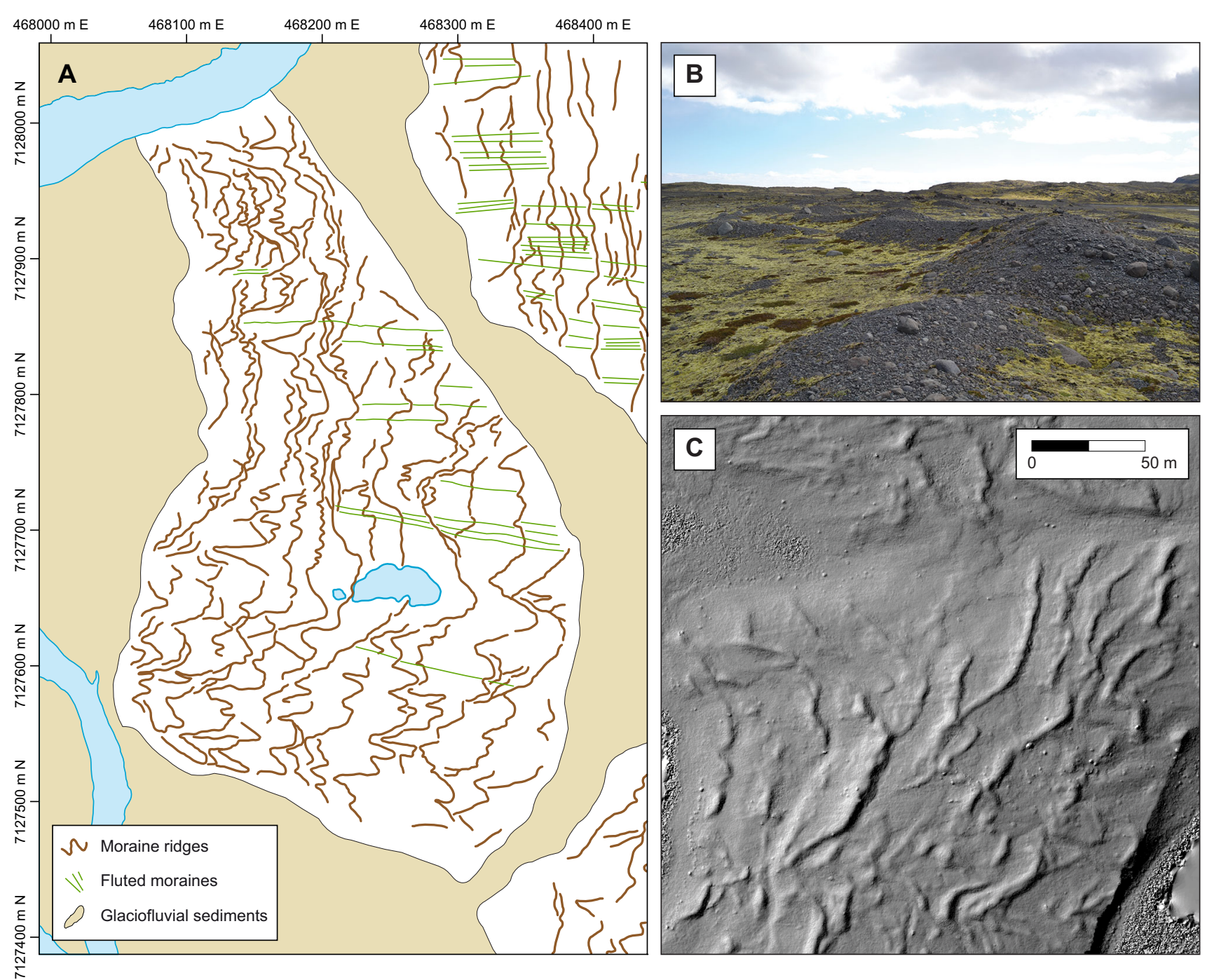

Fig. 3 Examples of annual moraines on the Skálafellsjökull, showing the distinctive 'sawtooth' planform of these features. a Excerpt from mapping by Chandler et al. [14] of annual moraines on the central part of the foreland. For the location, see Fig. 1. Scale and orientation are given by the Eastings and Northings. Projection: WGS 1984/UTM Zone $28 \mathrm{~N}$ (ESPG: 32628). b Field photograph showing the

present, and demonstrate that ice-frontal retreat is associated with elevated summer (ablation season) temperatures (see also $[9,10]$. We take our previous work, and that conducted on annual moraines elsewhere, further by undertaking statistical analysis (Wilcoxon rank-sum tests) to examine the differences/similarities between key phases of retreat in our record and the associated climate variations.

\section{Methods}

Before detailed examination of the ice-front retreat record (moraine spacing) can be undertaken, it must be demonstrated that the moraines represent successive annual ice- characteristic geometry of the moraines (22.05.2014). c Digital Elevation Model (DEM) visualised as a hillshaded relief (illumination angle $=30^{\circ}$; azimuth $=315^{\circ}$ ). The DEM was generated using UAVcaptured imagery and structure-from-motion photogrammetry (see [14], for further details)

frontal positions. This was achieved by describing, analysing and interpreting: (a) the distribution and geomorphology of the moraines; (b) the chronology of the moraines; and (c) moraine sedimentology (cf. [13]). On this basis, annual ice-frontal retreat rates have been calculated for the period covered by the moraine record (1936-1964, 1969-1974 and 2006-2011) using crest-tocrest (i.e. longitudinal) spacing (cf. [9, 42]). Moraine spacing was measured in ArcMap along a number of transects through the annual moraine sequences on the central and northern parts of the foreland, as no part of the foreland contains a 'complete' sequence covering the entire period. The sub-metre resolution of the imagery utilised in mapping ensures that the accuracy and precision of the 
mapped moraines are sufficient to calculate spacing to the nearest metre: (a) high-resolution scans of 2006 colour aerial photographs $[0.41 \mathrm{~m}$ Ground Sampled Distance (GSD)]; (b) pansharpened multispectral (8-band) WorldView-2 satellite imagery captured in June $2012(0.5 \mathrm{~m}$ GSD); and (c) a Digital Elevation Model (DEM) generated from Unmanned Aerial Vehicle (UAV)-captured imagery (spatial resolution: $0.09 \mathrm{~m}$ ). To assess the statistical significance of the differences between periods of pronounced glacier recession identified in the record of ice-frontal retreat, unpaired Wilcoxon rank-sum (or Mann-Whitney U) tests have been applied (cf. [47]). We also conduct timeseries analysis of climate data (ambient air temperatures and sea surface temperatures) for the entire period covered by the moraine record at Skálafellsjökull, and then compare the climate anomalies associated with the prominent periods we investigated.

\section{Results}

\section{Ice-frontal retreat record}

The record of ice-frontal retreat at Skálafellsjökull, calculated from the annual moraine record, indicates that the glacier underwent ice-frontal retreat in every year between 1936 and 1964 (average: $25.6 \mathrm{~m} \mathrm{a}^{-1}$ ). This is the longest sustained period of glacier recession during the $\sim 80$-year period examined (Fig. 4). Gaps in the record of ice-frontal retreat at Skálafellsjökull (1965-1968) and (1975-2005) represent periods during which annual moraine production ceased. Ice-front measurements conducted by the Icelandic Glaciological Society also show net glacier recession in every year during the period 1932-1957, with a paucity of data during the 1960s (e.g. [56]). According to the moraine record, the most rapid rates of ice-front retreat during the earliest period of glacier recession occurred in the late 1930s and early 1940 s, before a reduction in rates of ice-frontal retreat in the latter part of the 1940s (Fig. 4). More pronounced glacier recession again occurred during the mid-1950s, before ice-frontal retreat slowed in the early 1960s. Aerial photographs captured by Landmalingar Íslands (National Land Survey of Iceland) suggest that some sectors of the Skálafellsjökull ice-front subsequently underwent re-advance sometime during 1964-1969. Unfortunately, there is an absence of ice-front measurement data from Skálafellsjökull to corroborate this, with no measurements taken during the period 1969-1989. Nevertheless, this appears to be a common pattern across all Icelandic nonsurge-type glaciers, with many of them advancing to varying degrees during the 1960s (cf. [59]). A short period of annual moraine formation occurred at Skálafellsjökull between 1969 and 1974, with ice-front retreat averaging $9.9 \mathrm{~m} \mathrm{a}^{-1}$ over this time. Annual moraine formation ceased at the ice-margin following 1974 and did not subsequently recommence until during winter 2005/2006. Remote-sensing observations and ice-front measurements show that, during the intervening period, the glacier was relatively stable (1975-1989) before advancing in the 1990s, though the available data are sporadic: only 3 icefront measurements were taken during the 1990s (1992, 1993 and 1995). However, observations at other Icelandic non-surge-type glaciers do show similar terminus variations (e.g. [56, 58, 59]), indicating that re-advance was common across Iceland at this time. Although the icefrontal record used here only extends to 2012, continued ice-frontal retreat (and moraine production) was evident during fieldwork conducted at the glacier in 2014.

Based on the record of ice-frontal retreat, we identify two key 6-year periods (1936-1941 and 1951-1956) of icefrontal retreat for comparison with the most recent phase of retreat (2006-2011). During the most recent period, the Skálafellsjökull ice-front retreated $134 \mathrm{~m}$, with an average ice-front retreat rate of $\sim 22 \mathrm{~m} \mathrm{a}^{-1}$ (maximum retreat rate: $44 \mathrm{~m} \mathrm{a}^{-1}$ ). However, the two earlier periods identified exhibited more pronounced glacier recession. A total icefront retreat distance of $200 \mathrm{~m}$ occurred between 1936 and 1941, at an average of $\sim 33 \mathrm{~m} \mathrm{a}^{-1}$ (maximum retreat rate: $41 \mathrm{~m} \mathrm{a}^{-1}$ ). Similarly, the period 1951-1956 displayed icefrontal retreat totalling $\sim 197 \mathrm{~m}$, at an average of $\sim 33 \mathrm{~m}$ $\mathrm{a}^{-1}$. Moreover, the greatest ice-front recession in any given year occurs in $1953(\sim 50 \mathrm{~m})$. Statistical analysis conducted to examine the difference between these periods (Table 1) indicates that no statistically significant differences exist between the three periods of pronounced icefront retreat. Thus, glacier recession during these 6-year periods was comparable both in style and magnitude. Recent ice-frontal retreat (2006-2011) at Skálafellsjökull is, therefore, not unusual in the context of the $\sim 80$-year period examined in this study.

\section{Inter-annual variability in climate}

In our previous analysis of the overall retreat record and climate drivers, we demonstrated that the Skálafellsjökull ice-margin appears to be most sensitive to summer ambient air temperature (AAT) variations [13], in accordance with previous comparisons (e.g. [9, 59]). Additionally, we also showed that summer sea surface temperatures (SSTs) may have an (indirect) influence on ice-front retreat at this outlet. Based on this, we present time-series analysis of summer AATs and SSTs since the 1930s in this section and then, subsequently, compare the anomalies associated with 


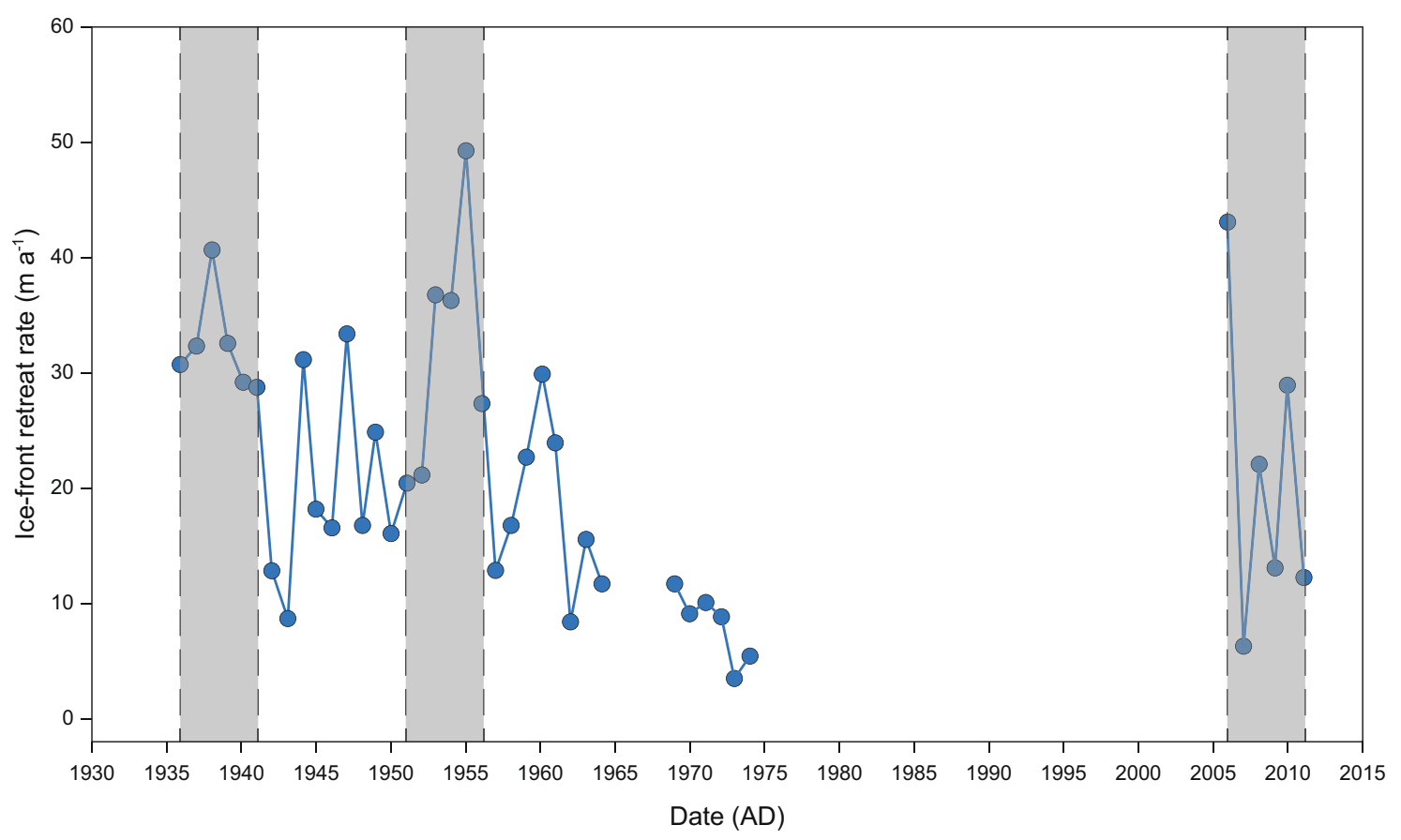

Fig. 4 Annual ice-front retreat rates at Skálafellsjökull calculated from annual moraine crest-to-crest spacing (see "Methods"). Shading indicates the three periods of ice-frontal retreat (1936-1941;
1951-1956; and 2006-2011) examined in this study. Gaps in the record reflect periods where annual moraine production ceased at the ice-front

Table 1 Comparison of three prominent periods of ice-frontal retreat at Skálafellsjökull, SE Iceland

\begin{tabular}{|c|c|c|c|c|c|c|}
\hline \multirow[t]{2}{*}{ Period } & \multirow{2}{*}{$\begin{array}{l}\text { Minimum retreat rate } \\
\left(\mathrm{m} \mathrm{a}^{-1}\right)\end{array}$} & \multirow{2}{*}{$\begin{array}{l}\text { Maximum retreat rate } \\
\left(\mathrm{m} \mathrm{a}^{-1}\right)\end{array}$} & \multirow{2}{*}{$\begin{array}{l}\text { Average retreat rate } \\
\left(\mathrm{m} \mathrm{a}^{-1}\right)\end{array}$} & \multicolumn{3}{|c|}{ Wilcoxon rank-sum test } \\
\hline & & & & 1936-1941 & $1951-1956$ & 2006-2011 \\
\hline 1936-1941 & 30 & 41 & 33 & - & $\mathrm{NS}^{\mathrm{a}}$ & NS \\
\hline 1951-1956 & 22 & 50 & 33 & NS & - & NS \\
\hline 2006-2011 & 8 & 44 & 22 & NS & NS & - \\
\hline
\end{tabular}

${ }^{a} N S$ no statistically significant difference

the prominent periods of ice-frontal retreat identified in the record.

For the purposes of analysing inter-annual variability in summer AAT, values have been used from Hólar í Hornafirði $\left(64^{\circ} 17.995^{\prime} \mathrm{N}, 15^{\circ} 11.402^{\prime} \mathrm{W} ; 16.0 \mathrm{~m}\right.$ a.s.l. $)$, the nearest long-term weather station to Skálafellsjökull. During the period 1930-2012, the mean and median summer AAT values at this weather station were $9.44{ }^{\circ} \mathrm{C}$ $\left(\sigma=0.65{ }^{\circ} \mathrm{C}\right)$ and $9.33^{\circ} \mathrm{C}$, respectively. The maximum negative deviation of summer AAT $\left(-1.09{ }^{\circ} \mathrm{C}\right)$ from the 1961-1990 average $\left(9.03^{\circ} \mathrm{C}\right)$ occurs in 1979 (Fig. 5a): remote-sensing observations suggest that the ice-margin was relatively stable at this time. Meanwhile, the maximum positive deviation in summer AAT during the period 1930-2012 was $1.87^{\circ} \mathrm{C}$, occurring in 1933 , preceding the formation of the oldest moraine in our record. The period 2002-2006 exhibits the greatest positive AAT anomaly for any 5-year period on record, with an average of $1.21{ }^{\circ} \mathrm{C}$. Furthermore, during the period 2003-2012, 5 years exhibit temperature anomalies greater than $1.5^{\circ} \mathrm{C}$. The longest period of consecutive years with negative AAT anomalies occurs between 1968 and 1971, with an average of $-0.25{ }^{\circ} \mathrm{C}$. Despite these negative anomalies, annual moraine production (and ice-frontal retreat) did occur during this period (see Fig. 4). Other periods with consecutive negative summer AAT anomalies occur between 1963 and 1965 (average: $-0.34{ }^{\circ} \mathrm{C}$ ), and between 1981 and 1983 (average: $-0.55{ }^{\circ} \mathrm{C}$ ), with the latter being associated with a period of ice-front stability (see "Ice-frontal retreat record").

Summer SST anomalies have been extracted from the Second Hadley Centre SST dataset (HadSST2: [53]) to explore inter-annual variability in ocean surface conditions. SST anomalies were extracted from four grid cells 
Fig. 5 Time-series plots for a summer ambient air temperature (AAT) and b summer sea surface temperature (SST), and comparison with the

Skálafellsjökull ice-front retreat record. Summer season follows the convention of the Icelandic Meteorological Office (cf. [28]). Solid lines in $\mathbf{a}$ and $\mathbf{b}$ show 5 -year moving averages, with the climate variables reported as deviations from the respective 1961-1990 averages. Summer AAT data taken from Hólar í Hornafirði $\left(64^{\circ} 17.995^{\prime} \mathrm{N}\right.$, $15^{\circ} 11.402^{\prime} \mathrm{W} ; 16.0 \mathrm{~m}$ a.s.1.), the nearest long-term weather station to Skálafellsjökull. SST values are based on the average between latitudes $57.5-67.5^{\circ} \mathrm{N}$ and longitudes $7.5-17.5^{\circ} \mathrm{W}$, and were extracted from the HadSST2 dataset [53]. The three prominent periods of icefront retreat examined in this study are also indicated (dashed lines)

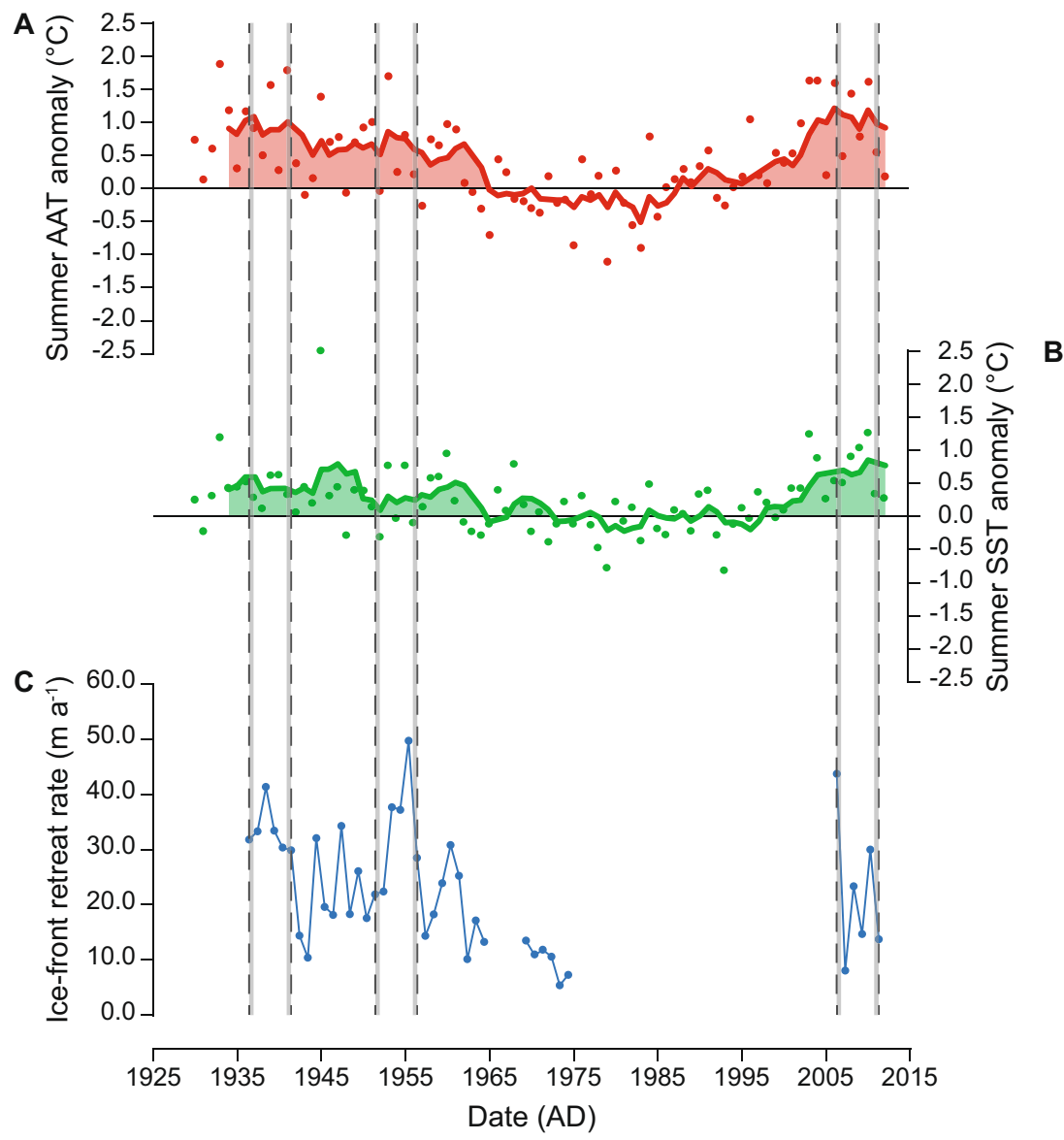

covering latitudes $57.5-67.5^{\circ} \mathrm{N}$ and longitudes $7.5-17.5^{\circ} \mathrm{W}$, with the values from the grid cells averaged to provide an indication of SST variations in proximity to SE Iceland. It should be noted that restricting the SST anomaly domain does not imply that SE Iceland climate is only influenced by variability in this region of the North Atlantic. Indeed, Icelandic climate may be influenced by variability in far-travelled ocean currents (cf. [51, 62]). The period 1930-2012 exhibited a mean summer SST anomaly of $0.24{ }^{\circ} \mathrm{C}\left(\sigma=0.48^{\circ} \mathrm{C}\right)$ in the domain identified, with SST values ranging from $-0.81{ }^{\circ} \mathrm{C}$ to $2.46{ }^{\circ} \mathrm{C}$. Prominent phases of positive SST anomalies occurred during the periods 1932-1941 (average anomaly: $0.48{ }^{\circ} \mathrm{C}$ ), 1958-1961 (average anomaly: $0.57{ }^{\circ} \mathrm{C}$ ) and 2001-2012 (average: $0.66^{\circ} \mathrm{C}$ ) (Fig. $5 \mathrm{~b}$ ). This latter period of elevated SST values coincides with a period of positive summer AAT anomalies, with AAT anomalies $>1.5{ }^{\circ} \mathrm{C}$ displayed on five occasions during 2003-2012 (see above). The coincidence of periods of elevated summer AATs and SSTs is demonstrated by least squares regression analysis (Fig. 6): the analysis indicates that $\sim 55 \%$ of the variance in summer AATs can be explained at an annual timescale ( $p<0.0001$ ), thus highlighting the importance of atmosphere-ocean interactions even at such short-term

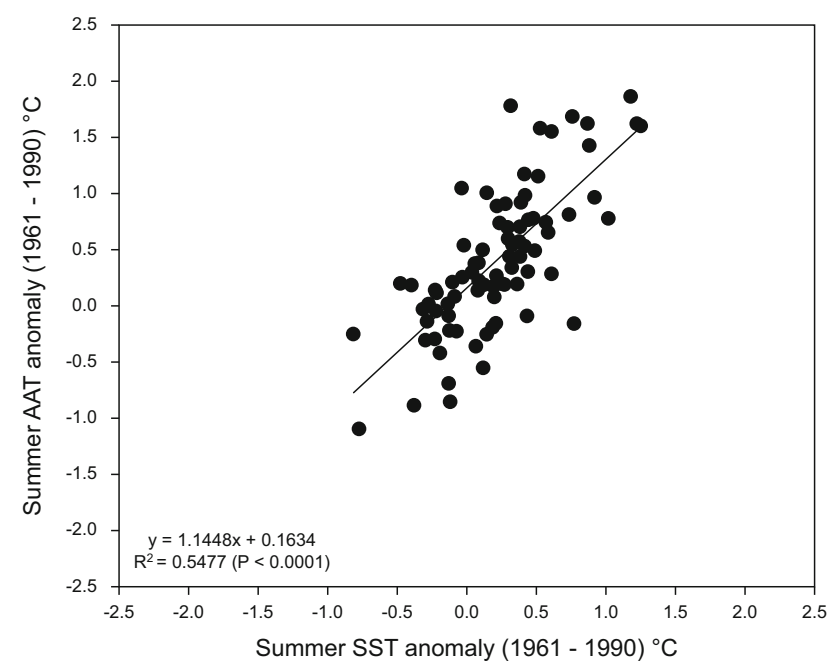

Fig. 6 Covariance plot showing variations in the summer (1st June30th September) signatures of ambient air temperature (AAT) and sea surface temperature (SST). Values for 1945 are excluded from the analysis of SST owing to a lack of SST data. The covariance analysis implies that SSTs have an influence on AATs, even at very short-term timescales

timescales. Two of the prolonged periods of positive SST anomalies (1932-1941 and 2001-2012) also occur concurrently with periods of pronounced ice-frontal retreat at 
Skálafellsjökull (see "Ice-frontal retreat record"). Conversely, the longest sustained period of negative annual SST anomalies lasts for 4 years, between 1962 and 1965 (average: $-0.19^{\circ} \mathrm{C}$ ): this is coincident with a period of negative summer AAT anomalies, identified above. Aside from this, there are two occasions in the record where negative SST anomalies persist for 3 years, in 1977-1979 (average: $-0.46{ }^{\circ} \mathrm{C}$ ) and $1992-1994$ (average: $-0.41{ }^{\circ} \mathrm{C}$ ). These two periods are coincident with ice-front stability or re-advance, according to remote-sensing observations and ice-front measurement data (see "Ice-frontal retreat record").

\section{Significance}

\section{Comparison with other Icelandic outlets}

The calculated ice-frontal retreat rates for Skálafellsjökull are comparable to retreat rates calculated from annual moraine spacing at other Icelandic outlet glaciers $[9,10]$. For the period 1936-1941, Lambatungnajökull underwent the same amount of glacier recession as Skálafellsjökull: the ice-front retreated $200 \mathrm{~m}$, at an average of $\sim 33 \mathrm{~m} \mathrm{a}^{-1}$ [9]. Meanwhile, the Falljökull ice-front retreated a distance of $310 \mathrm{~m}$ during the period 1935-1945, at an average of $\sim 28 \mathrm{~m} \mathrm{a}^{-1}$ [10]. Comparable ice-frontal retreat rates were displayed by Skálafellsjökull during the 1930s and 1940s, with the ice-front retreating $277 \mathrm{~m}$ between 1936 and 1945 (average: $\sim 28 \mathrm{~m} \mathrm{a}^{-1}$ ). This demonstrates that the glaciers underwent similar change during the twentieth century, and is supported by ice-front measurements from all non-surgetype outlet glaciers in Iceland (cf. [59]. More recently, Falljökull underwent $\sim 230 \mathrm{~m}$ of recession during the period 2005-2011 (average: $\sim 33 \mathrm{~m} \mathrm{a}^{-1}$ ), representing a significant increase in the rate of frontal retreat [10]. Falljökull has undergone ice-frontal retreat in every year since 1990, the longest series of net retreat on record at this glacier. Owing to this trend and the magnitude of icefront retreat, it has been argued that this recent very rapid retreat at Falljökull is an exceptional and unusual event [10]. This contrasts with Skálafellsjökull which has retreated by $134 \mathrm{~m}$ during the most recent phase of icefrontal retreat (2006-2011), with earlier periods in the record exhibiting greater glacier recession (see above). The differences evident between Falljökull and Skálafellsjökull are likely to reflect site-specific conditions, with the more rapid ice-frontal retreat rates and recent change in dynamics at Falljökull (cf. [10, 49, 50]) being a consequence of the smaller, steeper nature of the glacier, high mass turnover and the influence of an increasingly flooded overdeepening at the base of the icefall.

\section{Climate during the pronounced retreat periods}

Examination of the climate data shows that the most recent period of ice-frontal retreat (2006-2011) is associated with average summer AAT deviations of $+1.07{ }^{\circ} \mathrm{C}$ from the 1961-1990 average at Hólar í Hornafirði, whilst the earlier periods of glacier recession are associated with anomalies of $+1.03{ }^{\circ} \mathrm{C}(1936-1941)$ and $+0.66{ }^{\circ} \mathrm{C}(1951-1956)$. The period 2002-2006, preceding the most recent phase of retreat, exhibits the greatest positive AAT anomalies in any 5 -year period on record, with an average of $1.21^{\circ} \mathrm{C}$. Additionally, during the period 2002-2011, 5 years exhibit temperature anomalies $>1.5^{\circ} \mathrm{C} \quad(10$-year average: $+1.09^{\circ} \mathrm{C}$ ). Similarly, 3 years display summer AAT anomalies $>1.5^{\circ} \mathrm{C}$ between 1932 and 1941 (10-year average: $\left.+1.02{ }^{\circ} \mathrm{C}\right)$. Statistical analysis undertaken to examine these similarities indicates that no statistically significant differences exist between the summer AAT anomalies for these three periods (Table 2). Thus, the phases of pronounced glacier recession in 1936-1941 and 2006-2011 are associated with comparable summer AAT values.

Examination of SST anomalies shows that greater differences exist in summer SST between the phases of glacier recession. The most recent period of ice-frontal retreat at Skálafellsjökull (2006-2011) coincides with SST anomalies of $+0.75{ }^{\circ} \mathrm{C}$, whereas the earlier periods are associated with somewhat lower averages of $+0.40{ }^{\circ} \mathrm{C}$ (1936-1941) and $0.20^{\circ} \mathrm{C}$ (1951-1956), respectively. Additionally, three out of 6 years between 1951 and 1956 exhibit negative summer SST anomalies. During the period 1932-1941, only 1 year displays a positive summer SST anomaly $>1{ }^{\circ} \mathrm{C}\left(10\right.$-year average: $\left.+0.48^{\circ} \mathrm{C}\right)$. By comparison, the ten-year period $2002-2011$ experiences positive summer SST anomalies $>1{ }^{\circ} \mathrm{C}$ on three occasions (10-year average: $\left.+0.72{ }^{\circ} \mathrm{C}\right)$. Thus, the most recent phase of icefrontal retreat at Skálafellsjökull is associated with a phase of somewhat warmer summer SSTs. Nevertheless, Wilcoxon rank-sum tests performed on the data show that no statistically significant differences exist between the summer SST anomalies for the three periods (Table 2). It should also be recognised that the influence of SST variations on Icelandic termini variations is still relatively unknown. Statistically significant relationships have been identified between ice-frontal retreat at Skálafellsjökull and summer SST variations [13], but the coefficient of determination is low $\left(r^{2}=0.1623, p=0.0010\right)$. Additionally, no such relationships have been previously identified at other Icelandic glaciers and this, therefore, requires further exploration.

In this study, we have shown that both recent ice-frontal retreat at Skálafellsjökull and warming summer air temperatures in SE Iceland are not unusual in the context of the 
Table 2 Comparison of the climate variations associated with the three prominent periods of ice-frontal retreat at Skálafellsjökull, SE Iceland

\begin{tabular}{|c|c|c|c|c|c|c|}
\hline \multirow[t]{2}{*}{ Period } & \multirow{2}{*}{$\begin{array}{l}\text { Minimum anomaly } \\
\left({ }^{\circ} \mathrm{C}\right)\end{array}$} & \multirow{2}{*}{$\begin{array}{l}\text { Maximum anomaly } \\
\left({ }^{\circ} \mathrm{C}\right)\end{array}$} & \multirow{2}{*}{$\begin{array}{l}\text { Average } \\
\text { anomaly } \\
\left({ }^{\circ} \mathrm{C}\right)\end{array}$} & \multicolumn{3}{|c|}{ Wilcoxon rank-sum test } \\
\hline & & & & 1936-1941 & $1951-1956$ & 2006-2011 \\
\hline \multicolumn{7}{|c|}{ Summer AAT anomalies } \\
\hline $1936-1941$ & 1.03 & 1.79 & 0.29 & - & $\mathrm{NS}^{\mathrm{a}}$ & NS \\
\hline 1951-1956 & 0.66 & 1.69 & -0.03 & NS & - & NS \\
\hline 2006-2011 & 1.07 & 1.61 & 0.50 & NS & NS & - \\
\hline \multicolumn{7}{|c|}{ Summer SST anomalies } \\
\hline 1936-1941 & 0.11 & 0.61 & 0.40 & - & $\mathrm{NS}^{\mathrm{a}}$ & NS \\
\hline $1951-1956$ & -0.32 & 0.76 & 0.20 & NS & - & NS \\
\hline 2006-2011 & 0.33 & 1.25 & 0.75 & NS & NS & _- \\
\hline
\end{tabular}

Temperature anomalies represent deviations from the respective 1961-1990 averages

${ }^{a} N S$ no statistically significant difference

$\sim 80$-year records examined. Our findings are important at a time when glaciers both in Iceland (e.g. [29, 59] and elsewhere (e.g. [11, 25, 44, 60]) have shown accelerating rates of mass loss and retreat. Moreover, contemporary glacier change has been associated with unequivocal warming (e.g. [31]). This highlights the need for further and continued investigation of current glacier change, and the need for comparison with previous periods of icefrontal retreat in order to provide a broader context for current glacier variations. Individual outlet glaciers have also been shown to exhibit variable behaviour at short-term timescales (e.g. Skálafellsjökull and Falljökull), reflecting site-specific conditions. Although internal mechanisms are important, this signal will nonetheless be overridden by longer-term external forcing mechanisms, as demonstrated by the coincidence of phases of ice-front retreat and advance at Icelandic outlet glaciers (cf. [59]). The approach employed in this study has the capability to provide decadal to centennial-scale records of ice-front retreat, complementing observations of contemporary change (subdecadal to decadal-scale) and studies of the glacial geological record (millennial-scale).

\section{Complexity in the moraine record}

Although annual moraine spacing represents a valuable proxy for ice-frontal retreat, it should be recognised that there are a number of potential issues with utilising this approach and that there is complexity in recessional (annual) moraine records. The principal issue with using the Skálafellsjökull moraine record-and other moraine sequences-relates to establishing a robust moraine chronology. In this case, some uncertainty remains over the earliest moraines (pre-1945) in our record, as these formed before the first aerial photograph was captured (cf. [13]).
As a result, lichenometric dating of these features was undertaken, but it is recognised that this technique is associated with a number of uncertainties (e.g. $[33,48,64])$, bringing into question the validity of ages ascribed purely on the basis of lichenometric dating. Nevertheless, we have confidence in the dates of formation ascribed to these moraines given that remote-sensing data provide strong evidence for annual moraine formation both in this sequence and on other parts of the foreland (cf. [13]). Indeed, a number of previous studies have assumed that moraines formed on an annual basis if the number of ridges between two moraines of 'known' age is equal to the time elapsed between the formation of those reference moraines (e.g. [4, 9, 39, 41, 42]). Although sub-annual formation has been identified at the southeastern sector of the ice-front, we argue that this relates to specific conditions-the presence of a reverse bedrock slope, an aquiclude and highly saturated subglacial sediments-in this area of the foreland (see [13], for further details).

Depositional and erosional censoring may also affect the integrity (preservation) of the moraine sequences, thus reducing their representativeness of ice-frontal fluctuations (cf. [3, 26, 37, 38]). With respect to Skálafellsjökull, both self- and external censoring processes (sensu [38] may have impacted the annual moraine sequences to varying degrees. Firstly, there is some evidence of localised glacier overriding and superimposition of moraines (obliterative overlap) (cf. [13, 19]). Secondly, ice-cored moraines have previously been identified at Skálafellsjökull (cf. [55]) and meltout of debris-covered ice in ice-cored moraines may have impacted the moraine record (e.g. [1, 40, 42, 43, 54]). Although ice-cored moraines were not identified during excavations through moraines in 2014, their presence cannot be ruled out altogether and isolated, large dead-ice bodies were found underlying other surficial deposits [12]. 
Finally, glaciofluvial processes are a notable feature of active glacial landsystems (cf. [17, 20, 21], and references therein), and the moraine sequences have, in places, been partially affected by glaciofluvial activity (cf. [14, 19]. Although these processes introduce uncertainties, these were minimised by utilising multiple transects across the foreland (see "Methods").

Aside from these issues, it is also recognised that there is complexity in the links between the moraine record and climate. The annual moraines at Skálafellsjökull-and elsewhere in Iceland-primarily reflect seasonally driven submarginal processes active in a given year (cf. [13], and references therein), and will therefore largely reflect shortterm climate variability. This rapid short-term behaviour at the ice-front (glacier reaction time) should be distinguished from the integrated longer-term behaviour of the whole glacier (glacier response time), which is usually of the order of decades in maritime glaciers (cf. [2, 5, 10, 16, 27, 34]). Indeed, whilst the time lag between climate variation and the detection of change at the ice-front is small, it does not necessarily indicate that the ice-front has fully responded to the climate variation (cf. [5, 59]). Thus, our analyses demonstrate that Skálafellsjökull is currently reacting in a similar manner to previous periods in the 1930s, 1940s and 1950s. Nevertheless, the links between the moraine record and climate are inherently complex, and the record will integrate underlying longer-term climate variations (glacier response) in addition to short-term variations (glacier reaction), with multiple periodicities reinforcing or modulating each other (cf. [37, 38]).

\section{Conclusions}

Using the crest-to-crest spacing of annual moraines on the foreland of Skálafellsjökull, a temperate non-surging outlet glacier of the Vatnajökull ice-cap in SE Iceland, we calculated ice-frontal retreat rates since the 1930s. From the calculated record of ice-front retreat, we recognised two pronounced periods of glacier recession for comparison with the most recent phase of retreat (2006-2011). We undertook quantitative analysis to examine variability between these three periods of retreat, and showed that they are comparable both in style and magnitude. Analysis of climate data for SE Iceland also indicates that the three periods of ice-frontal retreat identified are associated with similar summer air temperature values, which has previously been shown to be a key control in terminus variations in Iceland. We, therefore, demonstrated that the coincidence of the most recent phase of ice-frontal retreat at Skálafellsjökull (2006-2011) and warming summer temperatures is not unusual in the context of the last $\sim 80$ years. This highlights the need to place observations of contemporary glacier change in a broader, longer-term (centennial) context. Moreover, the novel approach used in this study demonstrates the potential of annual moraine records for analysing ice-frontal variations where continuous records of glacier length change are absent or incomplete.

Acknowledgments Oddur Sigurðsson and Trausti Jónsson (both Icelandic Meteorological Office) kindly provided ice-front measurements and meteorological data, respectively. The UK Meteorological Office and British Atmospheric Data Centre granted access to the HadSST2 dataset. This research was supported by a Van Mildert College Postgraduate Award, Van Mildert College Principal's Award and QRA New Research Workers' Award. Hannah Bickerdike, Jonathan Chandler and Bertie Miles are thanked for assistance and companionship in the field. Regína Hreinsdóttir kindly granted permission to undertake fieldwork within the Vatnajökull National Park. The research was conducted under RANNÍS Agreement 4/2014. This paper is based on initial research completed by BMPC while an MSc student at Durham University.

Open Access This article is distributed under the terms of the Creative Commons Attribution 4.0 International License (http://crea tivecommons.org/licenses/by/4.0/), which permits unrestricted use, distribution, and reproduction in any medium, provided you give appropriate credit to the original author(s) and the source, provide a link to the Creative Commons license, and indicate if changes were made.

\section{References}

1. Andersen JL, Sollid JL (1971) Glacial chronology and glacial geomorphology in the marginal zones of the glaciers Midtdalsbreen and Nigardsbreen, south Norway. Nor Geogr Tidsskr 25:1-38. doi:10.1080/00291957108551908

2. Bahr DB, Pfeffer WT, Sassolas C, Meier MF (1998) Response time of glaciers as a function of size and mass balance: 1 . Theory. J. Geophys. Res.: Solid. Earth 103(B5):9777-9782. doi:10.1029/ 98JB00507

3. Barr ID, Lovell H (2014) A review of topographic controls on moraine distribution. Geomorphology 226:44-64. doi:10.1016/j. geomorph.2014.07.030

4. Beedle MJ, Menounos B, Luckman BH, Wheate R (2009) Annual push moraines as climate proxy. Geophys Res Lett 36:L20501. doi:10.1029/2009GL039533

5. Benn DI, Evans DJA (2010) Glaciers and Glaciation (2nd Edition). Hodder Education, London, p 802

6. Bennett MR (2001) The morphology, structural evolution and significance of push moraines. Earth-Sci Rev 53:197-236. doi:10. 1016/S0012-8252(00)00039-8

7. Björnsson H, Pálsson F, Guðmundsson S, Magnússon E, Adalgeirsdóttir G, Jóhannesson T, Berthier E, Sigurðsson O, Thorsteinsson T (2013) Contribution of Icelandic ice caps to sea level rise: Trends and variability since the Little Ice Age. Geophys Res Lett 40:1546-1550. doi:10.1002/grl.50278

8. Boulton GS (1986) Push moraines and glacier-contact fans in marine and terrestrial environments. Sedimentology 33:677-698. doi:10.1111/j.1365-3091.1986.tb01969.x

9. Bradwell T (2004) Annual moraines and summer temperatures at Lambatungnajökull, Iceland. Arct. Antarct Alp Res 36:502-508. doi:10.1657/1523-0430(2004)036[0502:AMASTA]2.0.CO;2

10. Bradwell T, Sigurðsson O, Everest J (2013) Recent, very rapid retreat of a temperate glacier in SE Iceland. Boreas 42:959-973. doi:10.1111/bor.12014 
11. Carr JR, Stokes CR, Vieli A (2014) Recent retreat of major outlet glaciers on Novaya Zemlya, Russian Arctic, influenced by fjord geometry and sea-ice conditions. J Glaciol 60:155-170. doi:10. 3189/2014JoG13J122

12. Chandler BMP (2015) Application of "annual" moraines to assess recent patterns and rates of ice-marginal retreat at Skálafellsjökull, SE Iceland. Unpublished MSc thesis, University of Durham, $199 \mathrm{pp}$

13. Chandler BMP, Evans DJA, Roberts DH (2016) Characteristics of recessional moraines at a temperate glacier in SE Iceland: Insights into patterns, rates and drivers of glacier retreat. Quat Sci Rev 135:171-205. doi:10.1016/j.quascirev.2016.01.025

14. Chandler BMP, Evans DJA, Roberts DH, Ewertowksi MW, Clayton AI (2016) Glacial geomorphology of the Skálafellsjökull foreland, Iceland: a case study of 'annual' moraines. J Maps 12(5):904-916. doi:10.1080/17445647.2015.1096216

15. Cogley JG (2009) Geodetic and direct mass-balance measurements: comparison and joint analysis. Ann Glaciol 50:96-100. doi:10.3189/172756409787769744

16. Cuffey KM, Paterson WSB (2010) The Physics of Glaciers (4th Edition). Butterworth-Heinemann, Burlington, p 693

17. Evans DJA (2003) Ice-marginal terrestrial landsystems: active temperate glacier margins. In: Evans DJA (ed) Glacial Landsystems, London, Arnold, pp 12-43

18. Evans DJA, Hiemstra JF (2005) Till deposition by glacier submarginal, incremental thickening. Earth Surf Process Landf 30(13):1633-1662. doi:10.1002/esp.1224

19. Evans DJA, Orton C (2015) Heinabergsjökull and Skalafellsjökull, Iceland: active temperate piedmont lobe and outwash head glacial landsystem. J. Maps 11:415-431. doi:10.1080/17445647. 2014.919617

20. Evans DJA, Twigg DR (2002) The active temperate glacial landsystem: a model based on Breiðamerkurjökull and Fjallsjökull, Iceland. Quat Sci Rev 21:2143-2177. doi:10.1016/S02773791(02)00019-7

21. Evans DJA, Ewertowski M, Orton C (2016) Fláajökull (north lobe), Iceland: active temperate piedmont lobe glacial landsystem. J Maps 12(5):777-789. doi:10.1080/17445647.2015.1073185

22. Eypórsson $J$ (1931) On the present position of the glaciers in Iceland: some preliminary studies and investigations in the summer 1930. Vísindafélag Isl, Rit, p 10

23. Eypórsson J (1935) On the variations of glaciers in Iceland. Some studies made in 1931. Geogr Ann 17:121-137

24. Eypórsson J (1963) Variation of Iceland glaciers 1931-1960. Jökull 13:31-33

25. Gardner AS, Moholdt G, Cogley JG, Wouters B, Arendt AA, Wahr J, Berthier E, Hock R, Pfeffer WT, Kaser G, Ligtenberg SRM, Bolch T, Sharp MJ, Hagen JO, van den Broeke MR, Paul F (2013) A reconciled estimate of glacier contributions to sea level rise: 2003 to 2009. Science 340:852-857. doi:10.1126/science. 1234532

26. Gibbons AB, Megeath JD, Pierce KL (1984) Probability of moraine survival in a succession of glacial advances. Geology 12:327-330. doi:10.1130/0091-7613(1984)12<327:POMSIA $>2$. $0 . \mathrm{CO} ; 2$

27. Haeberli W (1995) Glacier fluctuations and climate change detection: operational elements of a worldwide monitoring strategy. WMO Bull 44(1):23-31

28. Hanna E, Jónsson T, Box JE (2004) An analysis of Icelandic climate since the nineteenth century. Int $\mathrm{J}$ Climatol 24:1193-1210. doi:10.1002/joc.1051

29. Hannesdóttir H, Björnsson H, Pálsson F, Aðalgeirsdóttir G, Guðmundsson S (2015) Area, volume and mass changes of southeast Vatnajökull ice cap, Iceland, from the Little Ice Age maximum in the late 19th century to 2010. Cryosphere 9:565-585. doi:10.5194/tc-9-565-2015
30. Hiemstra JF, Matthews JA, Evans DJA, Owen G (2015) Sediment fingerprinting and the mode of formation of singular and composite annual moraine ridges at two glacier margins, Jotunheimen, southern Norway. Holocene 25(11):1772-1785. doi:10. $1177 / 0959683615591359$

31. IPCC (2013) Climate Change 2013: The Physical Science Basis. In: Stocker TF, Qin D, Plattner G-K, Tignor M, Allen SK, Boschung J, Nauels A, Xia Y, Bex V, Midgley PM (eds) Contribution of Working Group I to the Fifth Assessment Report of the Intergovernmental Panel on Climate Change. Cambridge University Press, Cambridge, p 1535

32. Jacob T, Wahr J, Pfeffer WT, Swenson S (2012) Recent contributions of glaciers and ice caps to sea level rise. Nature 482:514-518. doi:10.1038/nature10847

33. Jochimsen M (1973) Does the size of lichen thalli really constitute a valid measure for dating glacial deposits? Arct Alp Res 5(4):417-424

34. Jóhannesson T, Raymond C, Waddington E (1989) Time-scale for adjustment of glaciers to changes in mass balance. J Glaciol 35(121):355-369

35. Jóhannesson T, Sigurðsson O (1998) Interpretation of glacier variations in Iceland 1930-1995. Jökull 45:27-33

36. Kaser G, Cogley JG, Dyurgerov MB, Meier MF, Ohmura A (2006) Mass balance of glaciers and ice caps: consensus estimates for 1961-2004. Geophys Res Lett 33:L19501. doi:10.1029/ 2006GL027511

37. Kirkbride MP, Brazier V (1998) A critical evaluation of the use of glacier chronologies in climatic reconstruction, with reference to New Zealand. In: Owen LA (ed) Mountain Glaciation. Quaternary Proceedings N6, Supplement 1 to Journal of Quaternary Science, vol. 13. Wiley, Chichester, pp 55-64

38. Kirkbride MP, Winkler S (2012) Correlation of Late Quaternary moraines: impact of climate variability, glacier response, and chronological resolution. Quat Sci Rev 46:1-29. doi:10.1016/j. quascirev.2012.04.002

39. Krüger J (1995) Origin, chronology and climatological significance of annual moraine ridges at Mýrdalsjökull, Iceland. Holocene 5:420-427. doi:10.1177/095968369500500404

40. Krüger J, Kjaer KH (2000) De-icing progression in ice-cored moraines in a humid, sub-polar climate. The Holocene 10:737-747. doi:10.1191/09596830094980

41. Krüger J, Schomacker A, Benediktsson ÍÖ (2010) Ice-marginal environments: geomorphic and structural genesis of marginal moraines at Mýrdalsjökull. In: Schomacker A, Krüger J, Kjær K (eds) The Mýrdalsjökull Ice Cap, Iceland. Glacial Processes, Sediments and Landforms on Active Volcano, Developments in Quaternary Sciences, vol. 13, pp 79-104

42. Lukas S (2012) Processes of annual moraine formation at a temperate alpine valley glacier: insights into glacier dynamics and climatic controls. Boreas 41:463-480. doi:10.1111/j.15023885.2011.00241.x

43. Lukas S, Nicholson LI, Ross FH, Humlum O (2005) Formation, meltout processes and landscape alteration of high-arctic icecored moraines: examples from Nordenskiöld Land, central Spitsbergen. Polar Geogr 29:157-187. doi:10.1080/789610198

44. Marzeion B, Jarosch AH, Hofer M (2012) Past and future sealevel change from the surface mass balance of glaciers. Cryosphere 6:1295-1322. doi:10.5194/tc-6-1295-2012

45. Matthews JA, McCarroll D, Shakesby RA (1995) Contemporary terminal-moraine ridge formation at a temperate glacier: Styggedalsbreen, Jotunheimen, southern Norway. Boreas 24:129-139. doi:10.1111/j.1502-3885.1995.tb00633.x

46. Mernild SH, Hanna E, Yde JC, Seidenkrantz M-S, Wilson R, Knudsen NT (2014) Atmospheric and oceanic influence on mass balance of northern North Atlantic region land-terminating glaciers. Geogr Ann 96A:561-577. doi:10.1111/geoa.12053 
47. Miles BWJ, Stokes CR, Vieli A, Cox NJ (2013) Rapid, climatedriven changes in outlet glaciers on the Pacific coast of East Antarctica. Nature 500:563-566. doi:10.1038/nature12382

48. Osborn G, McCarthy D, LaBrie A, Burke R (2015) Lichenometric dating: science or pseudo-science? Quat Res 83(1):1-12. doi:10.1016/j.yqres.2014.09.006

49. Phillips E, Finlayson A, Bradwell T, Everest J, Jones L (2014) Structural evolution triggers a dynamic reduction in active glacier length during rapid retreat: Evidence from Falljökull, SE Iceland. J Geophys Res Earth Surf 119:2194-2208. doi:10.1002/ 2014JF003165

50. Phillips E, Finlayson A, Jones L (2013) Fracturing, block faulting, and moulin development associated with progressive collapse and retreat of a maritime glacier: Falljökull, SE Iceland. J Geophys Res Earth Surf 118:1-17. doi:10.1002/jgrf.20116

51. Phillips ID, Thorpe J (2006) Icelandic precipitation-North Atlantic sea-surface temperature associations. Int $\mathrm{J}$ Climatol 26:1201-1221. doi:10.1002/joc. 1302

52. Price RJ (1970) Moraines at Fjallsjökull, Iceland. Arct Alp Res 2:27-42

53. Rayner NA, Brohan P, Parker DE, Folland CK, Kennedy JJ, Vanicek M, Ansell TJ, Tett SFB (2006) Improved analyses of changes and uncertainties in sea surface temperature measured in situ since the mid-nineteenth century: the HadSST2 Dataset. J Climate 19:446-469. doi:10.1175/JCLI3637.1

54. Reinardy BTI, Leighton I, Marx PJ (2013) Glacier thermal regime linked to processes of annual moraine formation at Midtdalsbreen, southern Norway. Boreas 42(4):896-911. doi:10. 1111/bor. 12008

55. Sharp MJ (1984) Annual moraine ridges at Skálafellsjökull, southeast Iceland. J Glaciol 30:82-93

56. Sigurðsson O (1998) Glacier variations in Iceland 1930-1995: from the database of the Iceland Glaciological Society. Jökull $45: 3-25$
57. Sigurðsson O (2005) Variations of termini of glaciers in Iceland in recent centuries and their connection with climate. In: Caseldine C, Russell A, Harðardóttir J, Knudsen Ó (eds) Icelandmodern processes and past environments. Developments in Quaternary Sciences, vol. 5, pp 241-255

58. Sigurðsson O, Jónsson T (1995) Relation of glacier variations to climate changes in Iceland. Ann Glaciol 21:263-270

59. Sigurðsson O, Jónsson T, Jóhannesson T (2007) Relation between glacier-termini variations and summer temperatures in Iceland since 1930. Ann Glaciol 42:395-401. doi:10.3189/ 172756407782871611

60. Stokes CR, Shahgedanova M, Evans IS, Popovin VV (2013) Accelerated loss of alpine glaciers in the Kodar Mountains, south-eastern Siberia. Glob Planet Chang 101:82-96. doi:10. 1016/j.gloplacha.2012.12.010

61. Thórarinsson S (1967) Washboard moraines in front of Skeiðarárjökull. Jökull 17:311-312

62. Walter K, Graf HF (2002) On the changing nature of the regional connection between the North Atlantic oscillation and sea surface temperatures. J Geophys Res Atmos 107(D17):4338. doi:10. 1029/2001JD000850

63. Worsley P (1974) Recent "annual" moraine ridges at Austre Okstindbreen, Okstindan, north Norway. J Glaciol 13(68):265-277

64. Worsley P (1981) Lichenometry. In: Goudie A (ed) Geomorphological Techniques. George Allen and Unwin Ltd., London, pp 302-305

65. Zemp M, Hoelzle M, Haerberli W (2009) Six decades of glacier mass-balance observations: a review of the worldwide monitoring network. Ann Glaciol 50:101-111. doi:10.3189/ 172756409787769591 